\title{
Advances in the study of the spider (Aranei) fauna of Russia and adjacent regions: a 2011 update
}

\section{Итоги изучения фауны пауков (Aranei) России и прилезкащих регионов: обновление 2011 года}

\author{
Kirill G. Mikhailov \\ К.Г. Михайлов \\ Zoological Museum, Moscow Lomonosov State University, Bolshaya Nikitskaya Str. 6, Moscow 125009 Russia. E-mail: \\ mikhailov2000@gmail.com \\ Зоологический музей МГУ им. М.В. Ломоносова, ул. Б. Никитская, 6, Москва 125009 Россия.
}

KEY WORDS: biodiversity, spiders, physiographical regions, fauna, catalogue, Russia.

КЛЮЧЕВЫЕ СЛОВА: биоразнообразие, пауки, физико-географические регионы, фауна, каталог, Россия.

ABSTRACT. This paper contributes to global biodiversity research. Recent (2011) calculations of the spider species richness in Russia and the former Soviet Union republics, as well as in physiographical regions, are provided in comparison with earlier data. By 31st December 2011, 3,296 and 2,339 spider species have been reported from the FSU territories and Russia, respectively. An updated forecast on the expected spider diversity in the FSU and Russia faunas is given.

РЕЗЮМЕ. Приведенные в статье результаты многолетних исследований служат вкладом в изучение глобального биоразнообразия. В сравнении с более ранними данными, приведены современные (2011 год) подсчёты видового богатства пауков России и республик бывшего СССР, а также основных физико-географических регионов. По данным на 31 декабря 2011 г., с территории бывшего СССР и России соответственно отмечено 3296 и 2339 видов пауков. Приведен уточнённый прогноз разнообразия фауны пауков России и республик бывшего СССР.

The comparative data presented in this work are based on results of the long-term project started in 1981, against the background of a comprehensive study of animal/plant biodiversity undertaken by the Academy of Sciences of the former USSR. The aim of the entire project is to compile and critically assess all the available literature sources on spiders of Russia and other republics of the former Soviet Union (= FSU) since the 18th century. At present, the publication of all available data remains impossible, because a huge amount of information likely to run to several volumes of printed text and in all probability a task no publisher would be wiling to undertake. To date, only a checklist of spiders of the former USSR together with the bibliographical index covering all literature sources up to
July 2000 has been published [Mikhailov 1997, followed by several addenda].

The aim of this paper is to provide the most recent calculations (as of December 31st, 2011) of spider species numbers in order to demonstrate changes in the knowledge of the territory of the former USSR. Earlier calculations have been published in a number of articles [Mikhailov, 1992, 1997, 2002, 2012b, etc.]. An updated and the most complete bibliographical list has been published separately [Mikhailov, 2012a]. A new complete checklist of FSU spiders is under preparation.

Only very few catalogues culminating comparably long-term studies on certain invertebrate groups across such a vast territory as the FSU territory (ca 1/6th of the earth's surface) have been compiled. For instance, 4,033 species and sub-species of the FSU carabid beetles [Kryzhanovskij et al., 1995] distributed among 26 basic geographical regions "of the first order" and numerous smaller areas were listed, with general counts also being provided. A non-annotated catalogue of the Lepidoptera of Russia [Sinev, 2007] covering 40 administrative units rather than physiographical regions was compiled to include 8,879 species of Microlepidoptera and 3,832 species of Macrolepidoptera. Only a general list and numerous taxonomic/faunistic comments are given there. An annotated catalogue of the Heteroptera [Vinokurov et al., 2010] covering only the Asian part of Russia (Siberia and the Russian Far East) includes more than 1,200 species, of which distribution is presented using administrative units only; neither an analysis nor even counts of species or other taxa are provided.

Until now, 3,296 spider species have been reported from the FSU territories (Tables 1, 2). Since the 2000 evaluation, the main increase in species numbers has been documented for Linyphiidae (+106 species), followed by Gnaphosidae (+73), Lycosidae $(+70)$, Theri- 
Table 1. Species diversity of the main spider families, territory of the former USSR.

Таблица 1. Видовое разнообразие основных семейств пауков, территория бывшего СССР.

\begin{tabular}{|l|c|c|c|}
\hline \multirow{2}{*}{ Family } & \multicolumn{3}{|c|}{ Species number (percentage) } \\
\cline { 2 - 4 } & $\mathbf{2 0 0 0}$ & $\mathbf{2 0 0 9}$ & $\mathbf{2 0 1 1}$ \\
\hline Linyphiidae & $873(30.88)$ & $979(30.13)$ & $979(29.70)$ \\
Gnaphosidae & $294(10.40)$ & $357(10.99)$ & $367(11.13)$ \\
Salticidae & $307(13.19)$ & $338(10.40)$ & $340(10.32)$ \\
Lycosidae & $263(9.30)$ & $319(9.82)$ & $333(10.10)$ \\
Thomisidae & $168(5.94)$ & $177(5.45)$ & $179(5.44)$ \\
Theridiidae & $132(4.67)$ & $167(5.14)$ & $168(5.10)$ \\
Araneidae & $113(4.00)$ & $128(3.94)$ & $128(3.88)$ \\
Clubionidae & $99(3.50)$ & $112(3.45)$ & $113(3.43)$ \\
Philodro- & $74(2.62)$ & $92(2.83)$ & $94(2.85)$ \\
midae & & & \\
Dysderidae & $91(3.22)$ & $90(2.77)$ & $90(2.73)$ \\
Agelenidae & $54(1.91)$ & $80(2.46)$ & $81(2.46)$ \\
Dictynidae & $59(2.09)$ & $71(2.19)$ & $73(2.21)$ \\
others & 300 & 339 & 351 \\
\hline TOTAL & 2,827 & 3,249 & 3,296 \\
\hline
\end{tabular}

diidae $(+36)$ and Salticidae $(+32)$. The increase in species number was 510 during 1989-1995, or approximately 73 species annually. In 1996-2000, these figures were 130 and 33, respectively, in 2001-2011, 469 and 43.

The main spider families, viz. those represented by 70 or more species in 2011, are treated here (Table 1). Linyphiidae show the highest diversity, as expected. Gnaphosidae and Salticidae are the next two groups behind, their second and third places having been vice versa in 2000, but the same in 1996 and 1989 [Mikhailov, 2002]. According to the worldwide online catalogue [Platnick, 2012], Salticidae and Linyphiidae are the most species-rich families: 5,570 and 4,429 species of the total 43,678 , or 12.75 and $10.14 \%$, respectively. In the FSU territory, Salticidae showing predominantly tropical distribution is comparatively less speciose family than Linyphiidae and Gnaphosidae.

An analysis of the spider fauna of the post-Soviet (Table 2) republics has revealed almost the same relations as earlier: Russia supports the highest diversity (2,339 species), followed by Ukraine (996), Kazakhstan (879) and Azerbaijan (657). The spider faunas of Moldova and Armenia are not yet sufficiently studied. In Lithuania, a lot of species have been added since 2000, revealing its spider fauna similar to that of Latvia in the species number and its composition. In 20002011, the main increase in species richness is due to Russia (+365 species), Lithuania (+174), Ukraine $(+166)$, Kazakhstan $(+160)$ and Azerbaijan (+98), but not in Georgia and Kyrgyzstan as was the case in 1996-2000 [Mikhailov, 2002]. Only small changes have been recorded in Estonia, Latvia, Byelorussia, Moldova, Georgia, Armenia, and Middle (= Central) Asian republics. In 2001-2011, the activities of local arachnologists increased only in Russia, Lithuania, Ukraine and Azerbaijan (together with foreign specialists in the latter case) as compared to 1996-2000 data. The most considerable contribution to the knowledge of Kazakhstan spiders was made by visiting arachnologists.

Physiographical regions of the FSU territory are here accepted after Gvozdetsky (1968) (Fig. 1). The main increase during 2000-2011 concerns the Russian Plain (V, +321 species, or $31.29 \%$ of the 2000 number), continental southern Far East (T1, +295 species, or $52.12 \%$ ), the Crimea (E1, +166 species, or $48.54 \%$ ), the Caucasus (E2, +140 species, or $16.79 \%$ ), the mountains of South Siberia (P, +105 species, or $11.51 \%)$, West Siberia (M, +101 species, or $18.23 \%$ ) (see Table $3)$. It is interesting to note that in the continental southern Far East (Russia) crucial studies have mostly been performed by visiting arachnologists, while in the Crimea (Ukraine) by local specialists. Earlier, during 1996-2000, the main progress was made in West Sibe-

Table 2. Comparative species richness of the spider faunas in the FSU republics. Таблица 2. Сравнительное видовое богатство фаун пауков республик бывшего СССР

\begin{tabular}{|l|c|c|c|c|c|c|}
\hline \multirow{2}{*}{ Republics } & \multicolumn{6}{|c|}{ Years } \\
\cline { 2 - 7 } & $\mathbf{1 9 8 9}$ & $\mathbf{1 9 9 6}$ & $\mathbf{2 0 0 0}$ & $\mathbf{2 0 0 8}$ & $\mathbf{2 0 0 9}$ & $\mathbf{2 0 1 1}$ \\
\hline Former-USSR & 2,184 & 2,694 & 2,827 & 3,213 & 3,249 & 3,296 \\
Russia & & 1,874 & 1,974 & 2,260 & 2,297 & 2,339 \\
Estonia & & 506 & 509 & 505 & 507 & 511 \\
Latvia & & 401 & 402 & 414 & 415 & 419 \\
Lithuania & & 241 & 271 & 385 & 392 & 445 \\
Byelorus(sia) & & 383 & 412 & 418 & 421 & 424 \\
Ukraine & 808 & 830 & 936 & 958 & 996 \\
Moldova & & 291 & 292 & 292 & 292 & 292 \\
Georgia & 326 & 456 & 463 & 467 & 518 \\
Azerbaijan & & 500 & 559 & 642 & 644 & 657 \\
Armenia & & 118 & 127 & 134 & 135 & 136 \\
Kazakhstan & & 679 & 719 & 819 & 847 & 879 \\
Uzbekistan & & 290 & 309 & 320 & 321 & 330 \\
Turkmenistan & & 353 & 377 & 387 & 387 & 391 \\
Kyrgyzstan & & 358 & 464 & 474 & 476 & 477 \\
Tadjikistan & & 293 & 310 & 316 & 317 & 318 \\
\hline
\end{tabular}




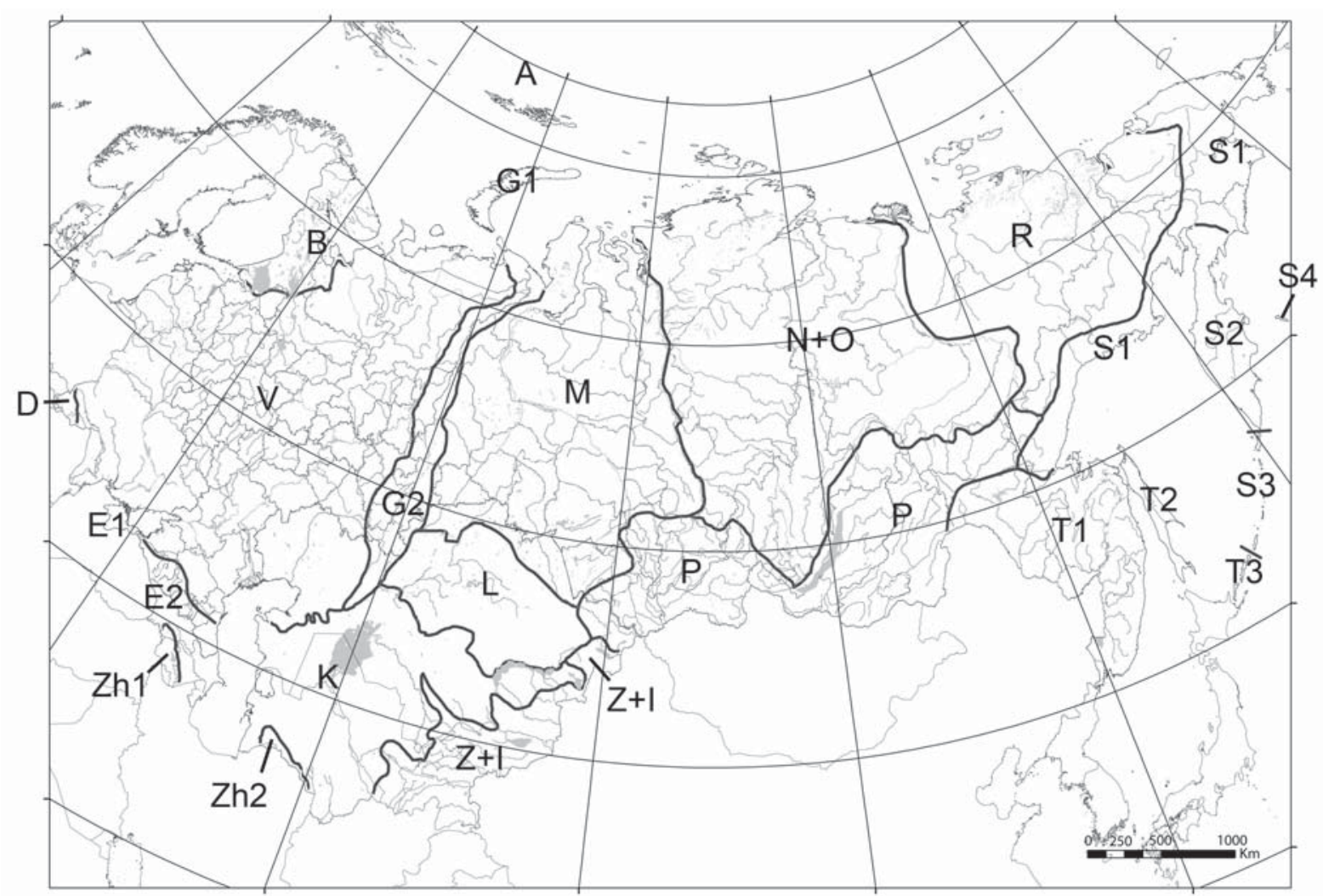

Fig. 1. Physiographical regions of the FSU after Gvozdetsky [1968]: A - Atlantic-Arctic area, B - Fennoscandia, V - Russian Plain, G1 - Novaya Zemlya, G2 - Urals, D - Carpathians, E1 - Crimea, E2 - Caucasus, Zh1 - Armenian Upland, Zh2 Kopetdagh Mts., Z+I - Mountains of Middle (=Central) Asia, K - Deserts of Middle (=Central) Asia, L — Kazakhstan hills, M - West Siberia, N+O - Middle Siberia, P - Mountains of South Siberia, R - Northeastern Siberia, S1 - Continental Far North-East, S2 Kamchatka, S3 - N-Kuriles, S4 - Commander Islands, T1 — Continental southern Far East, T2 — Sakhalin, T3 — S-Kuriles. English capital letters correspond to the Russian ones given in Gvozdetsky's book.

Рис. 1. Физико-географические регионы бывшего СССР, по Гвоздецкому [1968]: А — Атлантико-Арктическая область, В (Б) Фенноскандия, V (В) - Русская равнина, G1 (Г1) - Новая Земля, G2 (Г2) - Урал, D (Д) - Карпаты, Е1 - Крым, Е2 - Кавказ, Zh1 (Ж1) - Армянское нагорье, Zh2 (Ж2) - Копедаг, Z+I (3+И) - горы Средней Азии, K — пустыни Средней Азии, L (Л) Казахстанский мелкосопочник, $\mathrm{M}$ - Западная Сибирь, $\mathrm{N}+\mathrm{O}(\mathrm{H}+\mathrm{O})$ - Средняя Сибирь, $\mathrm{P}($ П) - горы Южной Сибири, $\mathrm{R}(\mathrm{P})-$ Северо-восточная Сибирь, S1 (C1) - континентальный Дальний Северо-Восток, S2 (C2) - Камчатка, S3 (C3) - Северные Курилы, S4 (C4) - Командорские о-ва, Т1 - континентальный юг Дальнего Востока, Т2 - Сахалин, Т3 - Южные Курилы.

ria (M, 29.91\% of the 1996 number), Fennoscandia (B, $20.28 \%$ ), the mountains of South Siberia (P, 12.18\%) and the Russian Far East (T1, 11.64\%).

The shares of the main spider families are shown in Figs 2-3. The regions such as the Armenian Upland and Kazakhstan Hills are discarded due to their too poorly known spider faunas. In the boreal areas ranging from Fennoscandia to Sakhalin Island, Linyphiidae predominate, with their proportion varying from 38 (Urals) to 59\% (Continental Far North-East). The share of Salticidae is high in Middle Asia (17-27\%), especially in the desert zone, being considerably less in boreal areas $(2-9 \%)$. In the southern regions such as the Carpathians, Crimea, Caucasus and Middle Asia, the proportions of both these families is less than 35\%, being closer to $50 \%$ in such intermediate regions as Russian Plain, the mountains of South Siberia or the continental southern Far East. The share of Gnaphosidae varies from 4 to $15 \%$, being especially low in the maritime regions of Russian Far East (4-7\%), but high enough in the Crimea and Middle Asia (13-15\%). Lycosidae are most diverse both in the mountains of South Siberia and northeastern Siberia (13\% each), with the minimum (4\%) in such remote areas as Kopet Dagh Mountains and Sakhalin Island. In most regions, the proportion of Thomisidae varies from 6 to $8 \%$, being extremely high $(11 \%)$ in Kopet Dagh Mountains and extremely low $(3 \%)$ in the continental Far North-East. The shares of Araneidae, Theridiidae and Philodromidae in different regions are $4-8,3-5$ and $3-5 \%$, respectively, or even less in the two latter families. Clubionidae are the most species-rich in the southern part of the Russian Far East (6-9\%), as opposed to 3\% or less in other regions. Dysderidae are sufficiently well represented in the Caucasus $(6 \%)$ only. Agelenidae, Dictynidae and Tetragnathidae scarcely reach $3-4 \%$ in any individual region.

The data provided herein are difficult to compare with the adjacent regions such as Europe, China or Japan. The recent country calculations are only avail- 
Table 3. Comparative species richness of the spider faunas in the FSU physiographical regions. Таблица 3. Сравнительное видовое богатство фаун пауков физико-географических регионов бывшего СССР.

\begin{tabular}{|c|c|c|c|c|c|c|}
\hline \multirow[t]{2}{*}{ Regions } & \multicolumn{6}{|c|}{ Years } \\
\hline & 1989 & 1996 & 2000 & 2008 & 2009 & 2011 \\
\hline $\mathbf{A}$ & 1 & 1 & 2 & 2 & 2 & 2 \\
\hline B & 385 & 429 & 516 & 532 & 534 & 554 \\
\hline $\mathbf{V}$ & 936 & 1,001 & 1,026 & 1,294 & 1,314 & 1,347 \\
\hline $\mathbf{G 1}+\mathbf{G} 2$ & 600 & & & & & \\
\hline G1 & & 21 & 21 & 20 & 24 & 24 \\
\hline G2 & & 683 & 750 & 786 & 790 & 795 \\
\hline D & 435 & 421 & 428 & 459 & 485 & 536 \\
\hline E1 & 308 & 311 & 342 & 478 & 500 & 508 \\
\hline E2+Zh1 & 671 & & & & & \\
\hline E2 & & 752 & 834 & 927 & 940 & 974 \\
\hline Zh1 & & 127 & 135 & 228 & 231 & 233 \\
\hline Zh2 & & 221 & 240 & 243 & 244 & 245 \\
\hline $\mathbf{Z}+\mathbf{I}$ & & 773 & 833 & 878 & 880 & 901 \\
\hline$\overline{\mathbf{K}}$ & 291 & 318 & 338 & 352 & 360 & 368 \\
\hline $\mathbf{L}$ & 103 & 129 & 143 & 160 & 160 & 171 \\
\hline $\mathbf{M}$ & 243 & 440 & 554 & 602 & 652 & 655 \\
\hline $\mathbf{N}+\mathbf{O}$ & 532 & 624 & 634 & 667 & 666 & 669 \\
\hline $\mathbf{P}$ & 436 & 813 & 912 & 1,002 & 1,015 & 1,017 \\
\hline $\mathbf{R}$ & 277 & 395 & 397 & 408 & 408 & 410 \\
\hline $\mathrm{S} 1+\mathrm{S} 2+\mathrm{S3}+\mathrm{S} 4$ & 278 & & & & & \\
\hline S1 & & 411 & 415 & 446 & 451 & 449 \\
\hline $\mathbf{S 2}$ & & 184 & 182 & 204 & 205 & 240 \\
\hline S3 & & 54 & 60 & 81 & 81 & 82 \\
\hline S4 & & 19 & 20 & 20 & 20 & 20 \\
\hline $\mathrm{T} 1+\mathrm{T} 2+\mathrm{T} 3$ & 375 & & & & & \\
\hline T1 & & 507 & 566 & 797 & 843 & 861 \\
\hline T2 & & 343 & 338 & 361 & 361 & 362 \\
\hline T3 & & 144 & 149 & 165 & 166 & 170 \\
\hline
\end{tabular}

Regions: A - Atlantic-Arctic area, B - Fennoscandia, V — Russian Plain, G1 — Novaya Zemlya, G2 - Urals, D - Carpathians, E1 - Crimea, E2 - Caucasus, Zh1 - Armenian Upland, Zh2 - Kopetdagh Mts., Z+I Mountains of Middle (=Central) Asia, K - Deserts of Middle (=Central) Asia, L - Kazakhstan hills, M - West Siberia, N+O - Middle Siberia, P - Mountains of South Siberia, R - Northeastern Siberia, S1 — Continental Far North-East, S2 - Kamchatka, S3 - N-Kuriles, S4 - Commander Islands, T1 - Continental southern Far East, T2 Sakhalin, T3 - S-Kuriles.

able for Europe [Helsdingen, 2013], with incomplete data for European Russia and Ukraine. A total of 2,361 spider species was registered in the whole territory of China earlier [Song et al., 1999]; currently, 3,714 species (Shuqiang Li, pers. comm.). To date, 1,574 species are known from Japan (A. Tanikawa, pers. comm.).

Earlier estimates of the total FSU spider fauna first amounted to 2,700-3,000 species [Mikhailov, 1992], later to 3,400-3,500 species [Mikhailov, 1997]. Current data allow us to further increase the forecast, with the total spider diversity of the FSU being likely to be 3,700-3,800 species and that of Russia 2,500-2,600 species. The FSU estimation is similar to that predicted for China: some 4,000 species (Shuqiang Li, pers. comm.). A faunistic study of the spiders of Russia and the FSU is yet far from complete.

Acknowledgements

I am deeply obliged both to Dr Sergei I. Golovatch (Moscow, Russia) and Dr Dmitry V. Logunov (Manchester, UK) for logistic and linguistic help. Dr Yuri
M. Marusik (Magadan, Russia) kindly supplied me with additional references on China and Japan.

\section{References}

Gvozdetsky N.A. 1968. [Physiographical regioning of the USSR]. Moscow: MGU Publishers. 576 p., 1 map [in Russian].

Helsdingen P.J. van. 2013. Fauna Europaea. Araneae. Available via http://www.european-arachnology.org/reports/fauna.shtml Accessed January 11th, 2013.

Kryzhanovskij O.L., Belousov I.A., Kabak I.I., Kataev B.M., Makarov K.V., Shilenkov V.G. 1995. A check-list of the Ground Beetles of Russia and adjacent lands (Insecta, Coleoptera, Carabidae). Sofia - Moscow: PENSOFT Publishers. 271 p.

Mikhailov K.G. 1992. [Results of the study of the USSR spider fauna] // Ovtsharenko V.I. (ed.). Fauna i ekologiya paukov, skorpionov i lozhnoskorpionov SSSR. Trudy Zoologicheskogo instituta AN SSSR, Leningrad. Vol.226. P.127-129 [in Russian].

Mikhailov K.G. 1997. Catalogue of the spiders of the territories of the former Soviet Union (Arachnida, Aranei) // Sbornik trudov Zoologicheskogo Museya MGU. Vol.37. 416 p.

Mikhailov K.G. 2002. The spider fauna of Russia and other postSoviet republics: a 2000 update // Toft S., Scharff N. (eds.). 


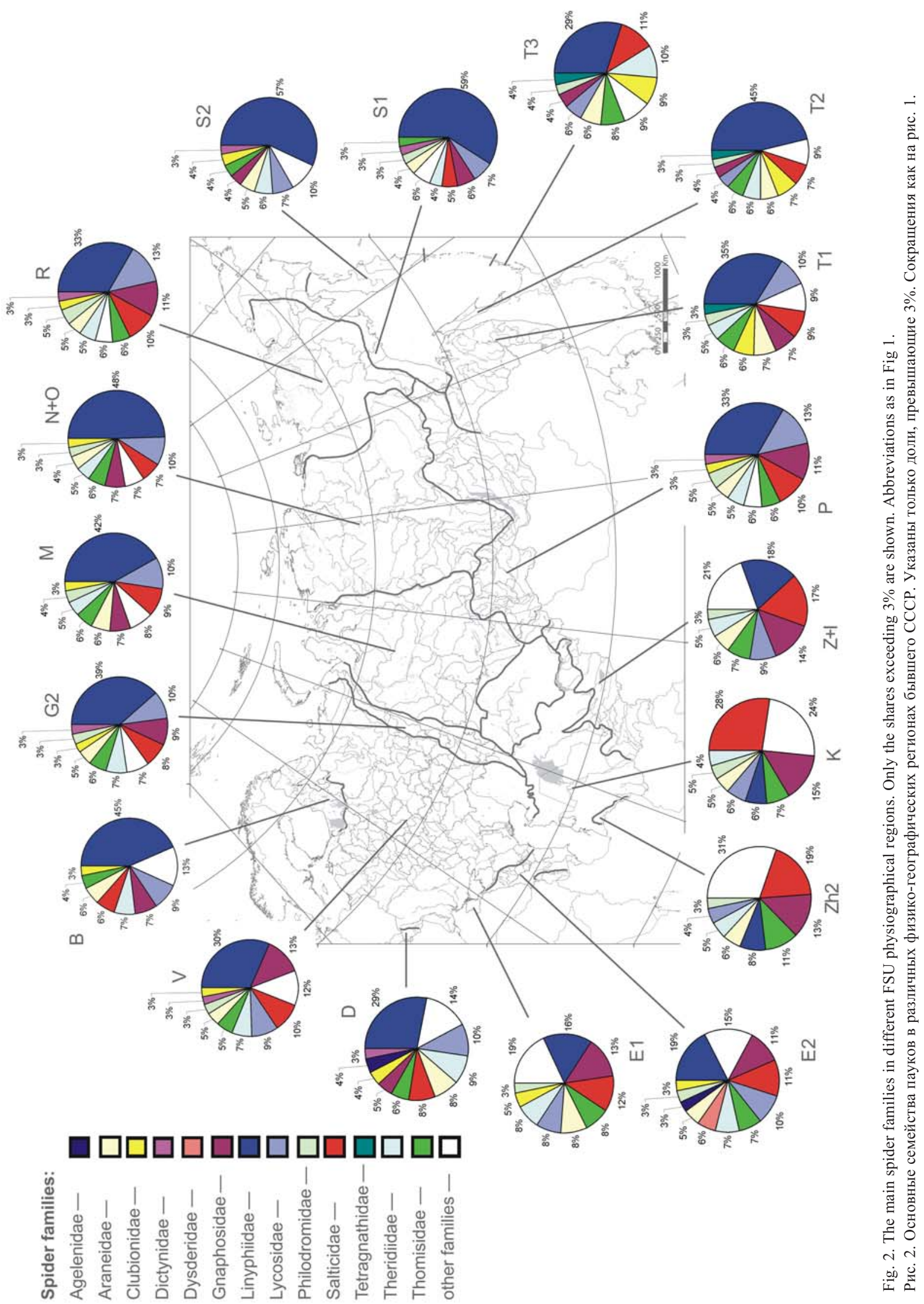




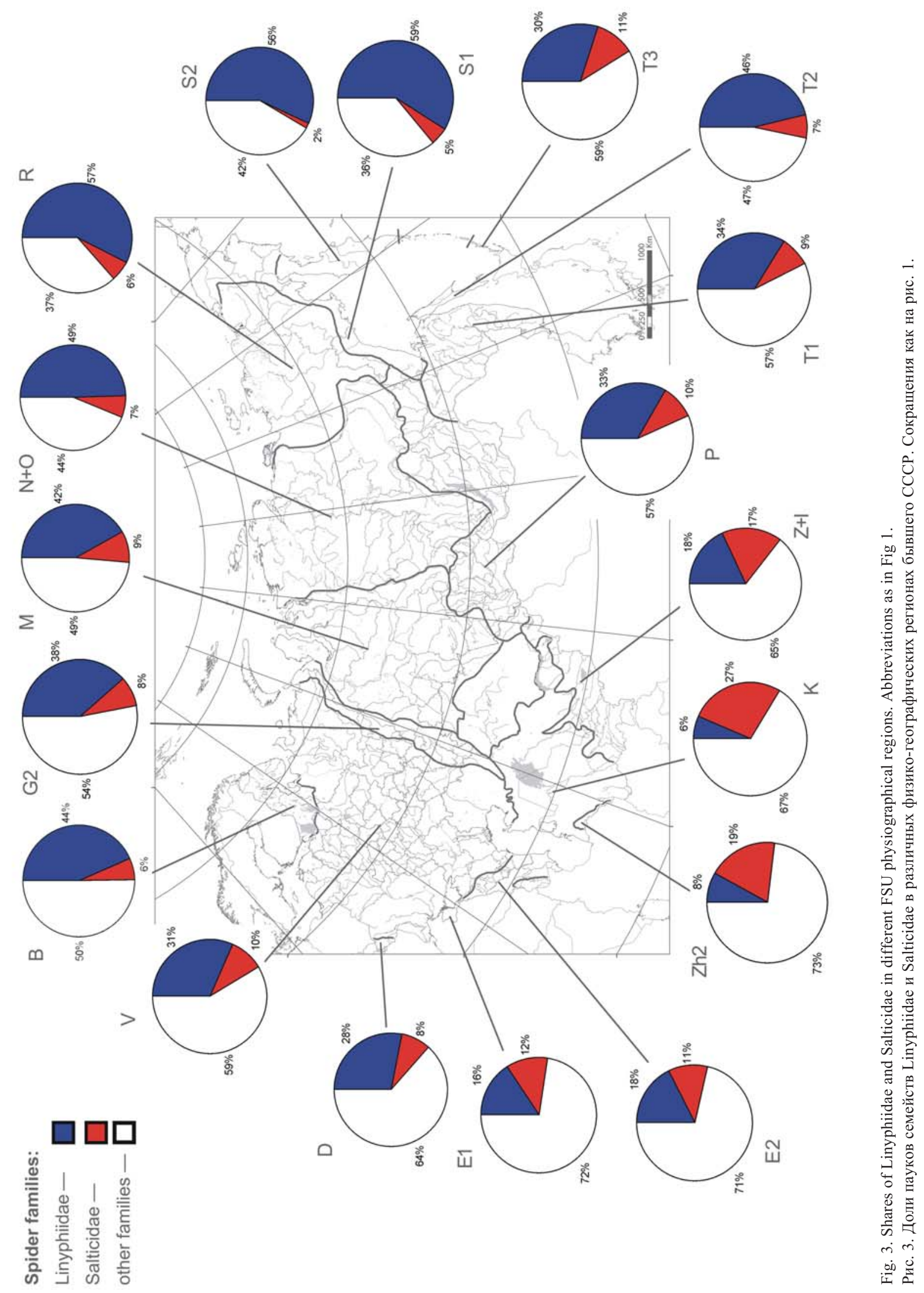


European Arachnology 2000. Proceedings of the $19^{\text {th }}$ European Colloquium of Arachnology, Århus 17-22 July 2000. Århus. P.255-259.

Mikhailov K.G. 2012a. [Bibliographia Araneologica Rossica 17702011] // Trudy Russkogo Entomologicheskogo obshchestva. Vol.83. No.2. 229 p. [in Russian, with English summary]

Mikhailov K.G. 2012b. The spider fauna of Russia and adjacent regions: a 2009 update // Russian Entomological Journal. Vol.21. No.1. P.165-168.

Platnick N.I. 2012. The World Spider Catalog. Version 13.5. American Museum of Natural History. Available via http://research. amnh.org/iz/spiders/catalog/INTRO1.html. Accessed December 24 th, 2012.
Sinev S.Yu. (ed.). 2007. [Catalogue of the Lepidoptera of Russia]. St.-Petersburg - Moscow: KMK Scientific Press Ltd. 424 p. [in Russian]

Song Daxiang, Zhu Mingsheng, Chen Ju. 1999. The spiders of China. Shijiazhuang: Hebei Science and Technology Publishing House. 640 p., 4 plates.

Vinokurov N.N., Kanyukova E.V., Golub V.B. 2010. [Catalogue of the Heteroptera of Asian part of Russia]. Novosibirsk: Nauka Publ. 319 p. [in Russian]

Responsible editor D.V. Logunov 